\title{
Illusory correlation in the remuneration of chief executive officers: It pays to play golf, and well.
}

\author{
Gueorgui I. Kolev \\ Universitat Pompeu Fabra, Department of Economics and Business, Ramon Trias Fargas 25-27, 08005 Barcelona, Spain. \\ Robin M. Hogarth
}

ICREA \& Universitat Pompeu Fabra, Department of Economics and Business, Ramon Trias Fargas 25-27, 08005 Barcelona, Spain.

\begin{abstract}
Illusory correlation refers to the use of information in decisions that is uncorrelated with the relevant criterion. We document illusory correlation in CEO compensation decisions by demonstrating that information, that is uncorrelated with corporate performance, is related to CEO compensation. We use publicly available data from the USA for the years 1998, 2000, 2002, and 2004 to examine the relations between golf handicaps of CEOs and corporate performance, on the one hand, and CEO compensation and golf handicaps, on the other hand. Although we find no relation between handicap and corporate performance, we do find a relation between handicap and CEO compensation. In short, golfers earn more than non-golfers and pay increases with golfing ability. We relate these findings to the difficulties of judging compensation for CEOs. To overcome this - and possibly other illusory correlations - in these kinds of decisions, we recommend the use of explicit, mechanical decision rules.
\end{abstract}

Key words: Illusory correlation; executive compensation; golf handicaps; decision rules.

JEL classification: D03, D81, J33

\section{Introduction}

Decisions concerning the remuneration of the chief executive officers (CEOs) of large corporations are important. Curiously, however, few studies have focused on the underlying judgmental processes that lead to these decisions. Instead, there seems to be an underlying belief that market forces will act to ensure that appropriate decisions are taken. ${ }^{1}$

\footnotetext{
${ }^{1}$ CEO's remuneration is just the price tag attached to the value of services that the CEO provides to the firm. According to the efficient market hypothesis (Samuelson, 1965; Fama, 1970) prices fully reflect all the available (relevant) information.
} 
Whereas it would be foolish to ignore the corrective power of market forces, it would be equally foolish to ignore the fact that judgments involving the remuneration of CEOs are fraught with difficulties. Not least of these is that such judgments - like many other complex, decision tasks depend on information that is only probabilistically related to the criterion of interest (Brunswik, 1952; Kahneman, Slovic, \& Tversky, 1982). For example, imagine estimating the future performance of a potential CEO. Clearly, some information - or cues - will be more important than others, the trackrecord of the candidate, say, or the type of problems facing the corporation. However, no one cue will be a perfect predictor and humans typically consider and aggregate several (Karelaia \& Hogarth, 2008).

The quality - or accuracy - of human judgment depends on factors that characterize the environment in which judgments are made and people's actions (Simon, 1956; Hammond, 1996). First, the predictive ability of available cues sets an upper limit on how well anyone can predict the criterion. Second, how people use these cues in their judgments, as well as their consistency in doing so, affects relative success. Ideal tasks for accurate judgment involve just a few highly predictive cues, repeated occasions on which judgments are made, and good feedback on outcomes (Karelaia \& Hogarth, 2008).

Judgmental tasks concerning the remuneration of CEOs are not "ideal." There are few good, predictive cues, the task is not repeated frequently (compare judging distances when driving), and feedback is unclear (e.g., delayed and/or distorted by extraneous factors). In these circumstances, the psychological literature suggests that people will be susceptible to different types of bias in the selection and weighting of different sources of information (Einhorn \& Hogarth, 1978; Gilovich, Griffin, \& Kahneman, 2002).

One such phenomenon has been termed "illusory correlation" (Chapman \& Chapman, 1967), and relates to using information systematically that is unrelated to the criterion of interest. This phenomenon was originally identified (and named) in the area of clinical psychology but it is not hard to see how it pervades many aspects of life. There have, for example, been many demonstrations of how physical height is used as a discriminating cue in situations such as job selection and political 
elections even when there is no basis to assume a veridical correlation between height and, say, competence (for a comprehensive review, see Judge \& Cable, 2004). Parenthetically, we add that people may or may not be aware that they are using illusory correlations. In some cases, these could arise from conscious beliefs that are just misconceived. In other cases, people might lack awareness about which cues affect their judgments.

This paper documents the role of illusory correlation in decisions about CEO remuneration. In short, in common with economic theory we assume that CEOs' remuneration should be related to the performance of the companies they manage. Second, we document a cue (or information about CEOs) that is unrelated to corporate performance. Third, we maintain that this cue is available to those making decisions about CEO performance, and that (a) those CEOs who exhibit the cue earn more than those that don't, and (b) remuneration is larger for CEOs who display more desirable values of the cue.

The cue in question is the CEO's golf handicap, a measure of how well a person plays the sport of golf. In short, possession of a handicap indicates whether or not a person plays golf on a regular basis and the actual handicap indicates ability. ${ }^{2}$ Our argument that this cue is available to those making remuneration decisions is based on the fact that, in addition to providing recreational facilities, golf clubs in the USA serve as important venues where wealthy investors, top business executives, board members and other relevant luminaries can meet and discuss. A CEO, therefore, can choose to be visible in such circles of influence.

This paper is organized as follows. Before describing the data used to test for illusory correlation, we discuss some related literature. Our actual tests follow two steps. The first is to show that there is no relation between golf handicap and corporate performance. The second is to document that CEOs with handicaps earn more than those that don't as well as the relation between handicap and remuneration. We conclude by discussing implications.

\footnotetext{
${ }^{2}$ Handicaps are administered by golf clubs or national associations such as the United States Golf Association. A handicap reflects how many more shots an amateur is expected to take to complete a round of golf than a hypothetical excellent player (or "par") - thus, the lower the handicap, the better the player.
} 


\section{Related literature}

This paper is most closely related to the small literature on pay for luck in CEO compensation in that it shows that this largely depends on a factor that has no place in standard principal-agent models. Indeed, one has to think hard and have a rich imagination to come up with a rational explanation for the empirical facts we report.

Bertrand and Mullainathan (2001) show that CEO pay responds as much to a lucky dollar as to a general dollar, contrary to what the basic principal-agent model predicts. As measures of luck in their analysis they use oil prices (for firms in the oil industry), average industry performance and exchange rate movements (for firms in the traded goods sector). Further they find that firms with stronger governance (e.g., firms where a large shareholder is present on the board of directors) pay less for luck.

Garvey and Milbourn (2006) demonstrate asymmetries in pay for luck - CEOs are rewarded for good luck, but are not punished for bad luck. The measure of luck they use is average industry performance.

Kolev (2008) shows that CEO pay is affected by the conditions in the public equity market, reflected in the number of IPOs and first day IPO returns. He argues that this is a manifestation of another judgmental bias, the "fundamental attribution error" ${ }^{3}$ - shareholders confuse good public equity market conditions for CEO leadership and skill.

There are extensions to the basic principle-agent model, which can make pay for luck potentially optimal - see, e.g., Oyer (2004), Himmelberg and Hubbard (2000), and Celentani and Loveira (2006). The key feature of these models is that CEO marginal productivity or the value of a CEO's outside options fluctuates. As these fluctuations can be potentially correlated with the state of the economy, pay for luck is not necessarily suboptimal - the state variables that we label "luck" are plausibly beyond the CEO's control, yet they might reflect the CEO's marginal productivity or values of outside options.

\footnotetext{
${ }^{3}$ Classic studies demonstrating the fundamental attribution error, i.e., people's tendency to attribute observed outcomes to internal dispositions and characteristics of agents (ability, skill, effort) as opposed to situational factors (exogenous shocks, luck) are Jones and Harris (1967) and Ross, Amabile and Steinmetz (1977). More recent and more relevant for the CEO compensation literature are Weber, Camerer, Rottenstreich, and Knez (2001) and Durell (2001).
} 
Blanchard, Lopez-de-Silanes, and Shleifer (1994) provide the most convincing evidence that CEO compensation in the USA has nothing to do with efficient compensation models and is a result of badly functioning corporate governance. They study the effect of cash windfalls, in the form of won or settled lawsuits, on CEO compensation. They start with a sample of 110 firms with settled lawsuits, and exclude all firms for which awards can be potentially connected to the firms' marginal Tobin's Q, thereby reaching a final sample of 11 firms. This method rules out the possibility that the effect of the cash windfall on CEO compensation is due to a change in the marginal productivity of the CEO. Further, their luck variable - cash windfall - is firm specific, hence the possibility that the effect of luck on pay is due to changing values of outside options is also discarded.

Blanchard et al. (1994) show that a median of $16 \%$ of the net award is given to the top three executives in the form of extra cash over the three years following the award. This increases cash compensation over the three years following the award by $84 \%$ compared to the three preceding years. Median management ownership rises from $14.5 \%$ before the award, to $16.5 \%$ after the award.

The empirical results in Blanchard et al. (1994) cast serious doubts on the empirical relevance of the models in Oyer (2004), Himmelberg and Hubbard (2000), and Celentani and Loveira (2006). Incidentally, none of the latter three papers quotes the former.

\section{Data}

The magazine Golf Digest compiles data on CEOs' golf handicaps biennially. For 1998, the Golf Digest ranking covers CEOs from the top 300 firms in the Forbes 500 list, and only data on those having US Golf Association handicap indices are included. For 2000, the ranking covers the 200 CEOs with the lowest handicaps (i.e., the 200 best players). For 2002, the Golf Digest CEO handicap ranking lists the top 270 golfers among Fortune 500 and $S \& P 500$ companies. For 2004, the ranking contains the top 234 golfers, again among Fortune 500 and $S \& P 500$ companies. Figure 1 in the Appendix A shows histograms of golf handicap by year.

We merged the data for the years 1998, 2000, 2002, and 2004 from issues of Golf Digest with Execucomp data on CEO compensation, stock returns and other control variables. To study how playing golf affects CEOs' remuneration and shareholders' returns we define three regressors. 
Handicap is the exact golf handicap of the CEO in the given fiscal year as reported in the corresponding year report of Golf Digest. No handicap is a dummy variable equal to 1 if the CEO does not appear in any Golf Digest ranking, and equal to 0 otherwise. We also compute the mean golf handicap for each CEO over the years in which he ${ }^{4}$ appears in rankings (e.g., if the CEO appears only in year 2000 ranking, then his mean golf handicap is the handicap for year 2000; if he appears in both the 2000 and 2002 rankings, his mean handicap is the average value of the handicap for year 2000 and the handicap for year 2002). We classify CEOs according to their mean golf handicap and define two dummy variables taking the value of 1 if the given CEO falls in the middle or the top tercile, respectively, of the mean golf handicap distribution. In the instrumental variable regressions the dummies denoting in which tercile of the mean handicap distribution the CEO falls are used as instruments for the exact golf handicap, i.e., we use them to compute Wald (1940) type of estimator.

\section{Results}

\subsection{CEO handicaps and shareholder returns}

The first step in our analysis is to establish that CEO golf handicap is not a relevant cue regarding CEO's ability to generate shareholder returns.

Tables 1 and 2 about here

Table 1 compares contemporaneous and one year ahead shareholders' returns for the group of CEOs appearing in the Golf Digest ranking to shareholders' returns for the group of CEOs who are not in the rankings. If golfers are better shareholder value maximizers, we should observe that they generate higher returns. Table 1 shows that this is not the case. CEOs who do not appear in any Golf Digest ranking appear to outperform the rest, and the effect is significant in the specifications in columns 1, 3 and 4. However the statistical significance of this finding is not robust to truncation of the top half percentile or top one percentile of returns. Furthermore, nearest neighbour matching estimators (Imbens, 2004; Abadie, Drukker, Herr \& Imbens, 2004) of the average treatment effect of not appearing in any ranking, a statistical method potentially more appropriate for a binary treatment

\footnotetext{
${ }^{4}$ The vast majority of CEOs were male.
} 
Gueorgui I. Kolev \& Robin M. Hogarth: Illusory correlation in the remuneration of chief executive officers: It pays to play golf, and well.

variable like No handicap, show that CEOs not appearing in any ranking outperform the rest but the effect is insignificant (see the Table B.1 in Appendix B, columns 1 and 2). Even if the effect is present, and the evidence is not overwhelming, it suggests that CEOs appearing in the golf ranking are less effective value maximizers for shareholders. If anything, they should be paid less than the others. ${ }^{5}$

Table 2 shows that among the CEOs who appear in the Golf Digest ranking, golf handicap and shareholders' returns are unrelated. The sign of the relation changes across specifications, and in no case can we reject the null hypothesis that golf handicap and shareholders' returns are unrelated. ${ }^{6}$

Finally, Figures 2 and 3 in Appendix A show the scatter plots of shareholders' returns versus golf handicap, together with the linear least squares fit. Returns are apparently randomly distributed across different levels of golf handicap, and no apparent relation is visible, neither monotonic nor nonmonotonic.

\subsection{CEO handicaps and compensation}

We start our analysis of the relation between golf handicap and CEO compensation by establishing that it exists. CEOs whose handicaps are good enough to warrant presence in the Golf Digest ranking are better paid and the effect is significant in all specifications at better than $1 \%$ significance level. As a robustness check we also employ nonparametric nearest neighbour matching estimators (see Appendix B). The average treatment effect of not playing golf from the matching estimators is much larger than the effect estimated from linear regression, and is significant at better than $0.1 \%$.

\footnotetext{
5 As a further robustness check we compute mean excess risk-adjusted returns, i.e., Jensen's alphas, from Jensen-FamaFrench-Carhart 4-factor models (Jensen, 1968; Fama \& French, 1993; Jegadeesh \& Titman, 1993; Carhart, 1997). We construct portfolios which are long in the stocks of CEOs not appearing in Golf Digest rankings, and short in the stock of the CEOs appearing in the rankings. When portfolios are constructed as equally weighted, CEOs without golf handicap seem to outperform the rest. When portfolios are constructed as value weighted, CEOs without golf handicap seem to underperform the rest. However, in no case is the Jensen's alpha statistically significant at conventional levels. For details see Appendix C, Table C.1. Overall and consistent with Table 1, whether the CEO appears in Golf Digest ranking or not does not seem to matter in a systematic way for long term CEO performance.

${ }^{6}$ As a further robustness check we compute excess risk-adjusted returns, i.e., Jensen's alphas, from Jensen-Fama-FrenchCarhart 4-factor models. We construct portfolios which are long in the stocks of CEOs who fall in the top and the middle tercile of the mean handicap distribution (not exceptionally good golf players), and short in the stock of the CEOs appearing in the bottom tercile of the mean handicap distribution (good golf players). The second tercile (average golf players) outperforms the first tercile (exceptionally good golf players), but the effect is insignificant at conventional levels (see Appendix C, Table C.2). The third tercile (relatively bad golf players) underperforms the first tercile (exceptionally good golf players), but the effect is insignificant at conventional levels (see Appendix C, Table C.3). Overall and consistent with results in Table 2, golf playing skills do not seem to matter for long term corporate performance.
} 
Among the set of executives present in the ranking, the ones who have higher handicaps (i.e., are worse golfers) are paid less.

Tables 3 and 4 establish these facts for the $\log$ of total direct compensation $[\log (\operatorname{tdc} 1)$ item in Execucomp], and Tables 5 and 6 do the same in respect of the log of total current compensation $[\log (\mathrm{tcc})$ item in Execucomp $]$.

Tables 3, 4, 5, and 6 about here

\subsection{CEO handicaps and compensation, conditional on other covariates}

Tables 3-6 show the results of regressing CEO compensation on golf handicap and other controls. Moving from column 1 to column 4 in each table, more regressors are included. Column 1 contains the bare minimum of controls relevant in this context - the size of the firm measured by the log of the market value. Column 2 adds a full set of year dummies. Column 3 adds other controls which might be relevant for explaining compensation - a dummy variable equal to 1 if the firm belongs to the $S \& P 500$ index, $\log$ of book to market ratio to proxy for firms' growth opportunities, 1 and 3 year stock returns (including dividend distributions), return on assets, number of employees, 3 year sales growth, price to earnings ratio, and dividend yield. Column 4, which is our preferred specification, additionally includes a full set of industry fixed effects at the 2 digit SIC level.

Table 3 explains the log of total CEO compensation [Salary, Bonus, Other Annual, Total Value of Restricted Stock Granted, Total Value of Stock Options Granted (using Black-Scholes), Long-Term Incentive Payouts, and All Other Total, i.e., tdc1 item in Execucomp] with a regressor which is a dummy variable taking the value 1 if the CEO does not have a golf handicap, or the handicap was not good enough to merit inclusion in any of the Golf Digest rankings. CEOs who are not regular golf players receive about $17 \%$ less $^{7}$ in total ex-ante compensation and the effect is significant at the $1 \%$ significance level (Table 3, column 4).

Table 4 is limited to the set of executives appearing in the Golf Digest rankings and presents regressions of the log of total CEO compensation on the CEO's golf handicap. Better golfers are paid

\footnotetext{
${ }^{7}$ More precisely, the marginal effect on CEO compensation from switching the No golf handicap dummy from 0 to 1 is $100 *[\exp (-0.1789)-1]=-16.3810 \%$
} 
more: an increase of one point in handicap (i.e., being a marginally worse player) results in $2.14 \%$ decrease in total ex-ante pay (Table 4, column 4). The effect is statistically significant at the $1 \%$ significance level and economically large. ${ }^{8}$

Table 5 presents regressions of the log of total current compensation comprised of salary and bonus (tcc item in Execucomp) on a dummy variable equal to 1 if the CEO does not have a handicap or if the handicap is not good enough to merit inclusion in the rankings, and other controls. Not playing golf regularly costs about $17 \%$ in total current compensation (Table 5, column 4), and the effect is significant at the $1 \%$ significance level. The sizes of the estimated effects of not playing golf for total current compensation are fairly similar to the estimated effects for total direct compensation.

The evidence supports our claim that CEOs who are regular golfers earn more than those who are not. At the same time, we stress that the effect is economically large - 17\% less in pay just because the CEO does not play golf or does not play golf regularly enough to have a decent handicap.

Table 6 presents regressions of the log of total current compensation on golf handicap and other covariates. Among the CEOs who have good golf handicaps - and hence appear in the Golf Digest rankings - an increase of one handicap point (i.e., being a marginally worse player) results in a decrease in salary and bonus of about $1 \%$ (Table 6, column 4). The effect is only statistically significant at the $12 \%$ significance level (i.e., insignificant at conventional levels), but economically quite large.

Finally, the mean CEO golf handicap in our sample is 14.85 with a standard deviation of 5.72 . Hence an increase in golf handicap of one standard deviation (i.e., becoming a worse golfer) leads to about $12 \%$ decrease in total ex-ante compensation and about an $6 \%$ decrease in salary plus bonus. This is strong evidence in support of our claim concerning the relative effects of golf handicap on remuneration.

\footnotetext{
${ }^{8}$ A good but not outstanding golfer might have a handicap of, say, 15. An outstanding golf player might have a handicap of 2 (i.e., plays nearly at par). Thus, a decrease in handicap from 15 to 2 , which is a move from being a good to an excellent golf player, results in about a $2.14 * 13=27.82 \%$ increase in total ex-ante compensation. This is a large effect.
} 


\subsection{CEO handicaps and compensation, instrumental variable regressions}

We argue that good golf playing abilities confer a "halo" effect on the CEO. The presence of the illusory belief that golf playing abilities correlate with shareholder value maximization abilities prompts the relevant decision makers (board of directors, compensation committee members) to confer higher pay on CEOs who are good golfers. Hence the thought experiment we have in mind is to elicit and somehow aggregate the opinions of all relevant decision makers regarding how good a golfer their CEO is, and to correlate this (infeasible) measurement of CEO golf playing abilities with CEO compensation.

As this experiment is infeasible in practice, the best measurement of how good a golfer a CEO is in the eyes of the relevant decision makers, is the golf handicap in the fiscal year in question. The theoretical variable we wish we could have regarding golf playing abilities is a weighted average of the opinions of the people deciding how much the CEO should be paid, where the weights reflect how important each person is in the decision making process. Therefore the golf handicap is an imperfect measurement of the theoretical variable we are interested in, even if the true golf handicap is measured without error in our data for the year in question.

If the decision makers' estimates of the CEOs' golf playing abilities diverge from the golf handicap in a random manner, as in the classical errors in variables model, i.e., the noise is uncorrelated with the golf handicap and with the error term in the estimating equation, our regressions of CEO remuneration on golf handicap would suffer from attenuation bias and we would underestimate the true effect of golf playing abilities on CEO pay. To investigate this issue, and correct for potential attenuation, we estimate instrumental variable regressions following a suggestion by Wald (1940). We use the tercile to which a CEO belongs in the handicap distribution (of CEO average handicaps) as an instrument for the golf handicap in the given year in question. ${ }^{9}$

Tables 7 and 8 about here

\footnotetext{
${ }^{9}$ We firstly compute the average golf handicap by CEO, e.g., if the CEO is present in the handicap rankings for years 2000 , 2002 and 2004 we take the average of the three; if he is present only for year 2000 we take the handicap for this year. Then we create dummy variables equal to 1 if the CEO belongs to the first, second or third tercile in this average handicap distribution, and use these dummy variables as instruments for the exact golf handicap in a given year. The idea is that this procedure provides another measurement of how good a golfer the CEO is in the eyes of the relevant decision makers.
} 
We find some evidence that our OLS handicap regressions are subject to attenuation. In the instrumental variable regressions the marginal effects of the golf handicap on CEO compensation become larger and statistically significant both for total direct compensation and total current compensation. For total direct compensation the instrumental variable estimate of the marginal effect of a unit increase in golf handicap is $-3.2 \%$ (Table 7 , column 4) versus the OLS estimate of $-2.14 \%$ (Table 4, column 4). For total current compensation the instrumental variable estimate of the marginal effect of a unit increase in golf handicap is $-1.9 \%$ (Table 8 , column 4) versus the OLS estimate of $-1.1 \%$ (Table 6, column 4). In the instrumental variable regression, the golf handicap appears as a significant predictor for total current compensation too $(\mathrm{p}$-value $=0.028$, Table 8 , column 4$)$, whereas this effect was insignificant at conventional levels in the OLS regression ( $\mathrm{p}$-value $=0.120$, Table 6 , column 4).

\section{Plausibility of alternative (rational) explanations of our results}

We consider two alternative explanations of our results that relate to reverse causality and unobserved productivity, respectively.

\subsection{Reverse causality - better paid CEOs are able to afford to play more golf}

In our sample, a CEO at the $10^{\text {th }}$ percentile of the distribution of total compensation receives about $\$ 1.5$ million. A CEO at the median receives more than $\$ 5$ million. Such levels of annual income are clearly not all spent on consumption. ${ }^{10}$ Hence even the poorest CEOs in our sample are rich enough to afford playing as much golf as they want - let alone notice the accompanying expense.

Prima facie evidence that CEOs are not really optimizing golf-playing related expenses is the fact that most belong to more than one golf club. ${ }^{11}$ Lastly, there is casual evidence that golf club memberships are considered a legitimate business expense and are often paid by the corporation (for examples, see the article quoted in the last footnote; for systematic evidence on this issue we will have to wait for improved $S E C$ requirements for disclosure of executive perquisites).

\footnotetext{
${ }^{10}$ Notice that buying a multi-million dollar mansion at the waterfront is not consumption, but investment as it will appreciate in value with the passage of time.

${ }^{11}$ An article in USA Today (July 11, 2006) entitled "CEOs belong to fore - or 5 or even 6 golf clubs" states: "a USA TODAY analysis of 115 CEOs and chairmen of Fortune 1,000 companies who also score good to excellent at golf found 51 who belong to at least two clubs, and 25 who belong to three or more." This could be an underestimate, as the Golf Digest survey for 2006 reports that $65 \%$ of CEO golfers who run Fortune 1,000 companies belong to at least two private country clubs and $45 \%$ belong to four or more.
} 


\subsection{Golf playing abilities correlated with unobserved productivity}

We admit that this is always a possibility and challenge readers to come up with a plausible explanation. What we have shown is that golf playing abilities are contemporaneously uncorrelated with a measurable and relevant criterion, shareholders' returns. Moreover, in the cross section, golf playing abilities do not meaningfully predict shareholders' returns one year ahead.

We conclude that the two alternative rational explanations are not plausible.

\section{Conclusions and implications}

Our results show clearly that information - or a cue - that is unrelated to corporate performance is related to the remuneration of CEOs. The presumption therefore is that this cue is used in remuneration decisions whether or not those making the decisions are conscious of its influence. We emphasize that given the inherent difficulty of assessing CEO compensation, it should come as no surprise that the underlying process of judgment is subject to bias. This is simply the nature of human information processing and leads to two questions. The first is why this particular cue - ability to play golf - plays an inappropriate role in these decisions. The second is what might be done to alleviate this, and possibly other biases, in the decision making process.

Given the social context in which CEO remuneration decisions are made, the underlying judgments undoubtedly involve a host of tangible and intangible measures ranging from concrete indicators of past performance to the observation of "soft" social skills and even physical appearance. Moreover, in the USA golf clubs provide locations in which the relevant actors socialize and can judge each other on a variety of dimensions. In this milieu, then, we suspect that being a good golfer is a positive attribute, generating its own "halo" effect. ${ }^{12}$

Since golf handicap does not predict corporate performance, what might be done about this and possibly other - illusory correlates? Our suggestion goes back to clinical psychology (where illusory correlation was identified) and the classic work of Meehl (1954) who showed that, even for complex diagnostic tasks, predictive ability is improved if human judgment is replaced by simple,

\footnotetext{
${ }^{12}$ Interestingly, an article in the Economist (April 10, 2008) entitled "Addressing the ball" states: "Many chief executives are obsessed with golf. Warren Buffet and Bill Gates are both keen players. Jack Welch, a former boss of General Electric, considered handicaps a good measure of business acumen."
} 
explicit statistical rules. Moreover, as demonstrated by a meta-analysis involving some 140 studies

(Grove et al., 2000), these findings have only been reinforced with time. As stated by the authors:

This study confirms and greatly extends previous reports that mechanical prediction is typically as accurate or more accurate than clinical prediction..........

Even though outlier studies can be found, we identified no systematic exceptions to the general superiority (or at least material equivalence) of mechanical prediction. It holds in general medicine, in mental health, in personality, and in education and training settings. It holds for medically trained judges and for psychologists. It holds for inexperienced and seasoned judges. (Grove et al., 2000, p. 25).

This does not, of course, mean that no human judgment is involved in mechanical prediction.

People still need to identify the variables that are used in formulas. Thus, if decision makers believe that golf handicap is a relevant variable for CEO compensation, it should be explicitly included in the equation. Given the inherent uncertainty in corporate performance, no decision rule - clinical or mechanical - can be a perfect predictor. However, to maximize expected shareholder value, one should clearly use the "best" rule available. 


\section{References}

Abadie, A., Drukker, D., Herr, J. L. \& Imbens, G. W. (2004). Implementing matching estimators for average treatment effects in Stata. Stata Journal, 4(3), 290-311.

Bertrand, M., \& Mullainathan, S. (2001). Are CEOs rewarded for luck? The ones without principals are. Quarterly Journal of Economics, 116 (3), 901-932.

Blanchard, O. J., Lopez-de-Silanes, F., \& Shleifer, A. (1994). What do firms do with cash windfalls? Journal of Financial Economics, 36(3), 337-360.

Brunswik, E. (1952). The Conceptual Framework of Psychology. Chicago, IL: The University of Chicago Press.

Carhart, M. (1997). On persistence in mutual fund performance. Journal of Finance, 52(1), 57-82.

Celentani, M., \& Loveira, R. (2006). A simple explanation of the relative performance evaluation puzzle. Review of Economic Dynamics, 9(3), 525-540.

Chapman, L. J., \& Chapman, J. P. (1967). Genesis of popular but erroneous psychodiagnostic observations. Journal of Abnormal Psychology, 72 (3), 193-204.

Durell, A. (2001). Attribution in performance evaluation. Dartmouth Dept. of Econ. Working Paper No. 01-07. Available at SSRN: http://ssrn.com/abstract=265210

Einhorn, H. J., \& Hogarth, R. M. (1978). Confidence in judgment: Persistence of the illusion of validity. Psychological Review, 85, 395-416.

Fama, E. (1970). Efficient capital markets: a review of theory and empirical work. Journal of Finance, 25(2), 383-417.

Fama, E. F. \& French, K. R. (1993). "Common risk factors in the returns on stocks and bonds," Journal of Financial Economics, 33(1), pages 3-56.

Garvey, G., \& Milbourn, T. (2006). Asymmetric benchmarking in compensation: executives are rewarded for good luck but not penalized for bad. Journal of Financial Economics, 82, 197-225.

Gilovich, T., Griffin, D., \& Kahneman, D. (2002). (Eds.) Heuristics and Biases: The Psychology of Intuitive Judgment. Cambridge, UK: Cambridge University Press. 
Grove, W. M., Zald, D. H., Lebow, B. S., Snitz, B. E., \& Nelson, C. (2000). Clinical versus mechanical prediction: A meta-analysis. Psychological Assessment, 12 (1), 19-30.

Hammond, K. R. (1996). Human judgment and social policy: Irreducible uncertainty, inevitable error, unavoidable injustice. Oxford, UK: Oxford University Press.

Himmelberg, C. P., \& Hubbard, R. G. (2000). Incentive Pay and the Market for CEOs: An Analysis of Pay-For-Performance Sensitivity. Available at SSRN: http://ssrn.com/abstract=236089

Imbens, G. (2004). Nonparametric estimation of average treatment effects under exogeneity: A review. Review of Economics and Statistics, 86(1), 4-29.

Jegadeesh, N. \& Titman, S. (1993). Returns to buying winners and selling losers: Implications for stock market efficiency. Journal of Finance, 48(1), 65-91.

Jensen, M. C. 1968. The Performance of Mutual Funds in the Period 1945-1964. Journal of Finance, 23(2), 389-416.

Jones, E. E., \& Harris, V. A. (1967). The attribution of attitudes. Journal of Experimental Social Psychology, 3, 1-24.

Judge, T. A., \& Cable, D. M. (2004). The effect of physical height on workplace success and income: preliminary test of a theoretical model. Journal of Applied Psychology, 89(3), 428-441.

Kahneman, D., Slovic, P., \& Tversky, A. (1982). (Eds.) Judgment under Uncertainty: Heuristics and Biases. Cambridge, UK: Cambridge University Press.

Karelaia, N., \& Hogarth, R. M. (2008). Determinants of linear judgment: A meta-analysis of lens model studies. Psychological Bulletin, 134 (3), 404-426.

Kolev, G. I. (2008). The stock market bubble, shareholders' attribution bias and excessive top CEOs pay. Journal of Behavioral Finance, 9(2), 62-71.

Meehl, P. E. (1954). Clinical versus Statistical Prediction: A Theoretical Analysis and a Review of the Evidence. Minneapolis, MN: University of Minnesota Press.

Oyer, P. (2004). Why do firms use incentives that have no incentive effects? The Journal of Finance, 59(4), 1619-1649. 
Ross, L., Amabile, T. M., \& Steinmetz, J. L. (1977). Social roles, social control, and biases in social perception. Journal of Personality and Social Psychology, 32, 880-892.

Samuelson, P. (1965). Proof that properly anticipated prices fluctuate randomly. Industrial Management Review, 6(2), 41-49.

Simon, H. A. (1956). Rational choice and the structure of environments. Psychological Review, 63, $129-138$.

Wald, A. (1940). The Fitting of straight lines if both variables are subject to error. Annals of Mathematical Statistics, 11(3), 284-300.

Weber, R., Colin Camerer, C., Rottenstreich, Y., \& Knez, M. (2001). The illusion of leadership: Misattribution of cause in coordination games. Organization Science, 12(5), 582-598.

Wooldridge, J. M., (2002). Econometric Analysis of Cross Section and Panel Data. Cambridge, MA: The MIT Press. 
Table 1: Mean shareholders' returns (\%) for firms where CEO does and does not have a golf handicap. In columns 1 and 2 the returns are for the current fiscal year. In columns 3 and 4 the returns are for the one year ahead fiscal year, i.e., in columns 3 and 4 we forecast future yearly returns.

\begin{tabular}{|c|c|c|c|c|}
\hline & $\begin{array}{l}(1) \\
\text { Return } 1 \text { year }\end{array}$ & $\begin{array}{c}(2) \\
\text { Return } 1 \text { year }\end{array}$ & $\begin{array}{c}\text { (3) } \\
\text { Future 1yr return }\end{array}$ & $\begin{array}{l}(4) \\
\text { Future } 1 \mathrm{yr} \text { return }\end{array}$ \\
\hline NO handicap & $\begin{array}{l}66.8313 * * \\
{[32.3557]}\end{array}$ & & $\begin{array}{l}32.4351 * * \\
{[16.1047]}\end{array}$ & \\
\hline Year $=1998$ & $\begin{array}{c}-9.7704 \\
{[37.3396]}\end{array}$ & $\begin{array}{c}16.2955 * * * \\
{[2.6200]}\end{array}$ & $\begin{array}{l}-9.3010 \\
{[13.3879]}\end{array}$ & $\begin{array}{l}9.9403 * * \\
{[4.2124]}\end{array}$ \\
\hline Year $=2000$ & $\begin{array}{l}-29.9329 \\
{[27.4203]}\end{array}$ & $\begin{array}{c}19.1384 * * * \\
{[3.3448]}\end{array}$ & $\begin{array}{c}49.4393 \\
{[38.6340]}\end{array}$ & $\begin{array}{c}3.1673 \\
{[2.0888]}\end{array}$ \\
\hline Year $=2002$ & $\begin{array}{l}-18.3665 \\
{[40.0530]}\end{array}$ & $\begin{array}{c}-12.1702 * * * \\
{[1.8408]}\end{array}$ & $\begin{array}{l}34.6796 * * \\
{[16.1727]}\end{array}$ & $\begin{array}{c}39.6580 * * * \\
{[3.5517]}\end{array}$ \\
\hline Year $=2004$ & $\begin{array}{l}109.0499 \\
{[77.9505]}\end{array}$ & $\begin{array}{c}19.0383 * * * \\
{[1.5299]}\end{array}$ & $\begin{array}{l}-14.9413 \\
{[13.7165]}\end{array}$ & $\begin{array}{c}8.4356 * * * \\
{[1.7355]}\end{array}$ \\
\hline NO handicap X yr1998 & & $\begin{array}{c}35.8110 \\
{[43.2945]}\end{array}$ & & $\begin{array}{l}8.8916^{*} \\
{[4.9622]}\end{array}$ \\
\hline NO handicap X yr2000 & & $\begin{array}{c}8.4573 \\
{[5.3756]}\end{array}$ & & $\begin{array}{c}87.8675 \\
{[61.6215]}\end{array}$ \\
\hline NO handicap X yr2002 & & $\begin{array}{c}59.4349 \\
{[49.7726]}\end{array}$ & & $\begin{array}{l}26.4457^{*} \\
{[15.9652]}\end{array}$ \\
\hline NO handicap X yr2004 & & $\begin{array}{c}172.5462 \\
{[117.8137]}\end{array}$ & & $\begin{array}{l}4.9316 * * \\
{[2.1985]}\end{array}$ \\
\hline $\begin{array}{l}\text { Interactions jointly zero: } \\
\text { F-statistic } \\
\text { (p-value) }\end{array}$ & $\mathrm{F}(4,3264)=$ & $\begin{array}{l}1.72 \\
(0.1419)\end{array}$ & $F(4,2716)=$ & $\begin{array}{l}3.36 \\
(0.0094)\end{array}$ \\
\hline $\begin{array}{l}\text { Observations } \\
R^{2}\end{array}$ & $\begin{array}{l}6807 \\
0.001\end{array}$ & $\begin{array}{l}6807 \\
0.001\end{array}$ & $\begin{array}{l}5581 \\
0.001\end{array}$ & $\begin{array}{l}5581 \\
0.001\end{array}$ \\
\hline
\end{tabular}

Note: We regress shareholders' returns in percentage form (Execucomp data item trs1yr) for the fiscal year (columns 1 and 2) and for the next fiscal year (columns 3 and 4) on a full set of time dummies (without a constant) and an indicator for whether the CEO does not appear in any Golf Digest golf handicap ranking (column 1 and 3). Hence in columns 1 and 3 the estimated coefficients on the time dummies are the mean returns for CEOs present in the Golf Digest golf handicap rankings and the estimate on the NO handicap dummy reflects the differential return for CEOs not present in the ranking. In columns 1 and 3 the differential return is constrained to be the same across years. In columns 2 and 4 full set of interactions is included. Hence the estimated coefficients on time dummies reflect the mean returns for CEOs present in any ranking in the given year, and the estimated coefficients on the (No handicap X year) interactions reflect the differential performance of CEOs not appearing in any ranking for the given year. The F-statistics test the null hypothesis that the four (No handicap $\mathrm{X}$ year) interactions are jointly equal to zero.

Standard errors [in brackets] consistent in the presence of arbitrary within CEO autocorrelation and heteroskedasticity (see Wooldridge 2002, eq. 7.26).

$* p<.10, * * p<.05, * * * p<.01$ 
Table 2: Measures of association between shareholders' returns (\%) and golf handicaps of CEOs. In columns 1 and 2 the returns are for the current fiscal year. In columns 3 and 4 the returns are for the one year ahead fiscal year, i.e., in columns 3 and 4 we forecast future yearly returns.

\begin{tabular}{|c|c|c|c|c|}
\hline & $\begin{array}{c}(1) \\
\text { Return } 1 \text { year }\end{array}$ & $\begin{array}{c}(2) \\
\text { Return } 1 \text { year }\end{array}$ & $\begin{array}{c}\text { (3) } \\
\text { Future 1yr return }\end{array}$ & $\begin{array}{l}(4) \\
\text { Future } 1 \mathrm{yr} \text { return }\end{array}$ \\
\hline Handicap & $\begin{array}{l}-0.0164 \\
{[0.2503]}\end{array}$ & & $\begin{array}{c}0.1643 \\
{[0.3494]}\end{array}$ & \\
\hline Year $=1998$ & $\begin{array}{c}16.3639 * * * \\
{[5.6320]}\end{array}$ & $\begin{array}{c}10.1639 \\
{[12.5529]}\end{array}$ & $\begin{array}{c}12.0601 \\
{[10.7881]}\end{array}$ & $\begin{array}{c}39.4294 \\
{[28.2488]}\end{array}$ \\
\hline Year $=2000$ & $\begin{array}{c}9.0900 \\
{[6.1401]}\end{array}$ & $\begin{array}{c}19.8486 \\
{[13.9483]}\end{array}$ & $\begin{array}{c}3.2744 \\
{[5.8750]}\end{array}$ & $\begin{array}{c}3.9078 \\
{[7.3718]}\end{array}$ \\
\hline Year $=2002$ & $\begin{array}{c}-13.1645 * * * \\
{[4.0737]}\end{array}$ & $\begin{array}{c}-16.0547 * * * \\
{[5.6407]}\end{array}$ & $\begin{array}{c}37.5630 * * * \\
{[4.6584]}\end{array}$ & $\begin{array}{c}26.9578 * * * \\
{[9.5601]}\end{array}$ \\
\hline Year $=2004$ & $\begin{array}{c}18.9111 * * * \\
{[3.7443]}\end{array}$ & $\begin{array}{c}16.0714 * * * \\
{[3.5590]}\end{array}$ & $\begin{array}{c}7.4676 \\
{[5.4135]}\end{array}$ & $\begin{array}{l}9.5077^{*} \\
{[5.2149]}\end{array}$ \\
\hline Handicap X yr1998 & & $\begin{array}{c}0.3852 \\
{[0.7438]}\end{array}$ & & $\begin{array}{l}-1.6591 \\
{[1.5014]}\end{array}$ \\
\hline Handicap X yr2000 & & $\begin{array}{c}-0.7117 \\
{[0.7699]}\end{array}$ & & $\begin{array}{c}0.1213 \\
{[0.4301]}\end{array}$ \\
\hline Handicap X yr2002 & & $\begin{array}{c}0.1782 \\
{[0.3734]}\end{array}$ & & $\begin{array}{c}0.8803 \\
{[0.7799]}\end{array}$ \\
\hline Handicap X yr2004 & & $\begin{array}{c}0.1844 \\
{[0.2423]}\end{array}$ & & $\begin{array}{c}0.0210 \\
{[0.3173]}\end{array}$ \\
\hline $\begin{array}{l}\text { Interactions jointly zero: } \\
\text { F-statistic } \\
\text { (p-value) }\end{array}$ & $\mathrm{F}(4,398)=$ & $\begin{array}{l}0.45 \\
(0.7729)\end{array}$ & $\mathrm{F}(4,331)=$ & $\begin{array}{l}0.61 \\
(0.6558)\end{array}$ \\
\hline $\begin{array}{l}\text { Observations } \\
R^{2}\end{array}$ & $\begin{array}{c}685 \\
0.148\end{array}$ & $\begin{array}{c}685 \\
0.153\end{array}$ & $\begin{array}{c}565 \\
0.098\end{array}$ & $\begin{array}{c}565 \\
0.106\end{array}$ \\
\hline
\end{tabular}

Note: We regress shareholders' returns in percentage form (Execucomp data item trs1yr) for the fiscal year (columns 1 and 2) and for the next fiscal year (columns 3 and 4) on the golf handicap for the given year (column 1 and 3). In columns 2 and 4 full set of interactions (Handicap X year) is included. The F-statistics test the null hypothesis that the four (Handicap X year) interactions are jointly equal to zero.

Standard errors [in brackets] consistent in the presence of arbitrary within CEO autocorrelation and heteroskedasticity (see Wooldridge 2002, eq. 7.26).

$* p<.10, * * p<.05, * * * p<.01$ 
Table 3: Regression of $\log$ of total compensation* on playing golf

\begin{tabular}{|c|c|c|c|c|}
\hline & $\begin{array}{c}1) \\
\text { Log(total comp. } \\
\text { expected) }\end{array}$ & $\begin{array}{c}(2) \\
\log (\text { total comp. } \\
\text { expected) }\end{array}$ & $\begin{array}{c}3) \\
\log (\text { total comp. } \\
\text { expected })\end{array}$ & $\begin{array}{c}(4) \\
\log (\text { total comp. } \\
\text { expected) }\end{array}$ \\
\hline NO handicap & $\begin{array}{c}-0.2337 * * * * \\
{[0.0495]}\end{array}$ & $\begin{array}{c}-0.2359 * * * \\
{[0.0495]}\end{array}$ & $\begin{array}{c}-0.1519 * * * \\
{[0.0578]}\end{array}$ & $\begin{array}{c}-0.1789 * * * \\
{[0.0591]}\end{array}$ \\
\hline Log(mktvalue) & $\begin{array}{c}0.3821 * * * \\
{[0.0118]}\end{array}$ & $\begin{array}{c}0.3812^{* * * *} \\
{[0.0119]}\end{array}$ & $\begin{array}{c}0.3894 * * * \\
{[0.0184]}\end{array}$ & $\begin{array}{c}0.4144 * * * \\
{[0.0192]}\end{array}$ \\
\hline $\log ($ book/mkt value $)$ & & & $\begin{array}{c}0.0645 * * * \\
{[0.0240]}\end{array}$ & $\begin{array}{c}0.0923 * * * \\
{[0.0249]}\end{array}$ \\
\hline S\&P 500 dummy & & & $\begin{array}{c}0.1215^{*} \\
{[0.0697]}\end{array}$ & $\begin{array}{c}0.0687 \\
{[0.0704]}\end{array}$ \\
\hline Return 1 year & & & $\begin{array}{c}0.0000 * * \\
{[0.0000]}\end{array}$ & $\begin{array}{c}0.0000 * * \\
{[0.0000]}\end{array}$ \\
\hline Return 3 years & & & $\begin{array}{c}0.0012 * * \\
{[0.0005]}\end{array}$ & $\begin{array}{c}0.0013 * * \\
{[0.0005]}\end{array}$ \\
\hline ROA & & & $\begin{array}{c}-0.0045^{* * *} * \\
{[0.0011]}\end{array}$ & $\begin{array}{c}-0.0050 * * * \\
{[0.0012]}\end{array}$ \\
\hline Sales growth 3yrs & & & $\begin{array}{l}0.0016^{*} \\
{[0.0008]}\end{array}$ & $\begin{array}{l}0.0013^{*} \\
{[0.0008]}\end{array}$ \\
\hline Employees & & & $\begin{array}{c}0.0005 \\
{[0.0003]}\end{array}$ & $\begin{array}{c}0.0004 \\
{[0.0003]}\end{array}$ \\
\hline Dividend yield & & & $\begin{array}{c}-0.0072 \\
{[0.0063]}\end{array}$ & $\begin{array}{c}-0.0000 \\
{[0.0026]}\end{array}$ \\
\hline Price/earnings & & & $\begin{array}{c}-0.0000 \\
{[0.0000]}\end{array}$ & $\begin{array}{c}-0.0000 \\
{[0.0000]}\end{array}$ \\
\hline Time dummies & No & Yes & Yes & Yes \\
\hline $\begin{array}{l}2 \text { digit SIC dummies } \\
\text { Constant }\end{array}$ & $\begin{array}{c}\text { No } \\
5.2432 * * * \\
{[0.1072]}\end{array}$ & $\begin{array}{c}\text { No } \\
5.0683 * * * \\
{[0.1091]}\end{array}$ & $\begin{array}{c}\text { No } \\
4.9331 * * * \\
{[0.1220]}\end{array}$ & $\begin{array}{c}\text { Yes } \\
4.8092 * * * \\
{[0.1215]}\end{array}$ \\
\hline $\begin{array}{l}\text { Observations } \\
R^{2}\end{array}$ & $\begin{array}{c}6706 \\
0.310\end{array}$ & $\begin{array}{l}6706 \\
0.318\end{array}$ & $\begin{array}{l}6099 \\
0.337\end{array}$ & $\begin{array}{l}6099 \\
0.371\end{array}$ \\
\hline
\end{tabular}

*The dependent variable is the log of total compensation, comprised of Salary, Bonus, Other Annual, Total Value of Restricted Stock Granted, Total Value of Stock Options Granted (using BlackScholes), Long-Term Incentive Payouts, and All Other Total (tdc1 item in Execucomp). The main regressor of interest NO handicap is a dummy variable equal to 1 if the CEO does not appear in any of the Golf Digest golf handicap rankings.

Standard errors [in brackets] consistent in the presence of arbitrary within CEO autocorrelation and heteroskedasticity (see Wooldridge 2002, eq. 7.26).

$* p<.10, * * p<.05, * * * p<.01$ 
Table 4: Regression of log of total compensation* on golf handicap

\begin{tabular}{|c|c|c|c|c|}
\hline & $\begin{array}{c}1) \\
\log (\text { total comp. } \\
\text { expected })\end{array}$ & $\begin{array}{c}(2) \\
\log (\text { total comp. } \\
\text { expected) }\end{array}$ & $\begin{array}{c}3) \\
\log (\text { total comp. } \\
\text { expected })\end{array}$ & $\begin{array}{c}\text { (4) } \\
\log (\text { total comp. } \\
\text { expected) }\end{array}$ \\
\hline Handicap & $\begin{array}{c}-0.0153^{* *} \\
{[0.0072]}\end{array}$ & $\begin{array}{c}-0.0149 * * \\
{[0.0072]}\end{array}$ & $\begin{array}{l}-0.0138^{*} \\
{[0.0077]}\end{array}$ & $\begin{array}{c}-0.0214 * * * \\
{[0.0080]}\end{array}$ \\
\hline Log(mktvalue) & $\begin{array}{c}0.3044 * * * \\
{[0.0455]}\end{array}$ & $\begin{array}{c}0.3004 * * * \\
{[0.0453]}\end{array}$ & $\begin{array}{c}0.2784 * * * \\
{[0.0815]}\end{array}$ & $\begin{array}{c}0.2399 * * * \\
{[0.0864]}\end{array}$ \\
\hline $\log ($ book/mkt value) & & & $\begin{array}{c}0.0897 \\
{[0.1165]}\end{array}$ & $\begin{array}{c}0.1526 \\
{[0.1026]}\end{array}$ \\
\hline Return 1 year & & & $\begin{array}{c}0.0014 \\
{[0.0018]}\end{array}$ & $\begin{array}{c}0.0023 \\
{[0.0016]}\end{array}$ \\
\hline Return 3 years & & & $\begin{array}{l}0.0087 * * \\
{[0.0040]}\end{array}$ & $\begin{array}{l}0.0086^{* *} \\
{[0.0037]}\end{array}$ \\
\hline ROA & & & $\begin{array}{c}-0.0034 \\
{[0.0116]}\end{array}$ & $\begin{array}{c}0.0028 \\
{[0.0127]}\end{array}$ \\
\hline Sales growth $3 y r s$ & & & $\begin{array}{c}-0.0065 \\
{[0.0043]}\end{array}$ & $\begin{array}{l}-0.0067 \\
{[0.0041]}\end{array}$ \\
\hline Employees & & & $\begin{array}{c}0.0004 \\
{[0.0005]}\end{array}$ & $\begin{array}{c}0.0009 \\
{[0.0006]}\end{array}$ \\
\hline Dividend yield & & & $\begin{array}{c}0.0041 \\
{[0.0252]}\end{array}$ & $\begin{array}{c}0.0263 \\
{[0.0177]}\end{array}$ \\
\hline Price/earnings & & & $\begin{array}{c}0.0003 \\
{[0.0002]}\end{array}$ & $\begin{array}{c}0.0003 \\
{[0.0002]}\end{array}$ \\
\hline S\&P 500 dummy & & & $\begin{array}{c}0.2499 \\
{[0.1952]}\end{array}$ & $\begin{array}{c}0.2442 \\
{[0.1827]}\end{array}$ \\
\hline Time dummies & No & Yes & Yes & Yes \\
\hline 2 digit SIC dummies & No & No & No & Yes \\
\hline Constant & $\begin{array}{c}6.1779 * * * \\
{[0.4527]}\end{array}$ & $\begin{array}{c}6.0141 * * * \\
{[0.4461]}\end{array}$ & $\begin{array}{c}5.9358 * * * \\
{[0.6024]}\end{array}$ & $\begin{array}{c}6.3589 * * * \\
{[0.6989]}\end{array}$ \\
\hline $\begin{array}{l}\text { Observations } \\
R^{2}\end{array}$ & $\begin{array}{c}676 \\
0.145\end{array}$ & $\begin{array}{c}676 \\
0.155\end{array}$ & $\begin{array}{c}644 \\
0.196\end{array}$ & $\begin{array}{c}644 \\
0.302\end{array}$ \\
\hline
\end{tabular}

*The dependent variable is the log of total compensation, comprised of Salary, Bonus, Other Annual, Total Value of Restricted Stock Granted, Total Value of Stock Options Granted (using BlackScholes), Long-Term Incentive Payouts, and All Other Total (tdc1 item in Execucomp). The main regressor of interest is Handicap, the golf handicap for the given year as reported in the relevant Golf Digest ranking.

Standard errors [in brackets] consistent in the presence of arbitrary within CEO autocorrelation and heteroskedasticity (see Wooldridge 2002, eq. 7.26).

$* p<.10, * * p<.05, * * * p<.01$ 
Table 5: Regression of log of total current compensation* on playing golf

\begin{tabular}{|c|c|c|c|c|}
\hline & $\begin{array}{c}(1) \\
\log \text { (total current } \\
\text { comp.) }\end{array}$ & $\begin{array}{c}\text { (2) } \\
\log \text { (total current } \\
\text { comp.) }\end{array}$ & $\begin{array}{c}(3) \\
\log (\text { total current } \\
\text { comp.) }\end{array}$ & $\begin{array}{c}\text { (4) } \\
\log (\text { total current } \\
\text { comp.) }\end{array}$ \\
\hline NO handicap & $\begin{array}{c}-0.2594 * * * \\
{[0.0493]}\end{array}$ & $\begin{array}{c}-0.2738 * * * \\
{[0.0492]}\end{array}$ & $\begin{array}{c}-0.1888 * * * \\
{[0.0605]}\end{array}$ & $\begin{array}{c}-0.1785 * * * \\
{[0.0599]}\end{array}$ \\
\hline Log(mktvalue) & $\begin{array}{c}0.2465^{* * * *} \\
{[0.0134]}\end{array}$ & $\begin{array}{c}0.2404 * * * \\
{[0.0135]}\end{array}$ & $\begin{array}{c}0.2698 * * * \\
{[0.0191]}\end{array}$ & $\begin{array}{c}0.2628 * * * \\
{[0.0212]}\end{array}$ \\
\hline $\log ($ book/mkt value) & & & $\begin{array}{c}0.1337 * * * \\
{[0.0209]}\end{array}$ & $\begin{array}{c}0.0945^{* * *} * \\
{[0.0221]}\end{array}$ \\
\hline S\&P 500 dummy & & & $\begin{array}{c}0.0072 \\
{[0.0689]}\end{array}$ & $\begin{array}{c}-0.0035 \\
{[0.0692]}\end{array}$ \\
\hline Return 1 year & & & $\begin{array}{c}0.0000 \\
{[0.0000]}\end{array}$ & $\begin{array}{c}0.0000 \\
{[0.0000]}\end{array}$ \\
\hline Return 3 years & & & $\begin{array}{c}0.0020 * * * \\
{[0.0006]}\end{array}$ & $\begin{array}{c}0.0014 * * * \\
{[0.0005]}\end{array}$ \\
\hline ROA & & & $\begin{array}{l}0.0019 * * \\
{[0.0008]}\end{array}$ & $\begin{array}{c}0.0009 \\
{[0.0007]}\end{array}$ \\
\hline Sales growth $3 y r s$ & & & $\begin{array}{c}-0.0017 * * \\
{[0.0007]}\end{array}$ & $\begin{array}{c}-0.0016^{* * *} \\
{[0.0007]}\end{array}$ \\
\hline Employees & & & $\begin{array}{l}0.0008^{*} \\
{[0.0004]}\end{array}$ & $\begin{array}{l}0.0008 * * \\
{[0.0004]}\end{array}$ \\
\hline Dividend yield & & & $\begin{array}{l}-0.0010 \\
{[0.0015]}\end{array}$ & $\begin{array}{c}0.0002 \\
{[0.0019]}\end{array}$ \\
\hline Price/earnings & & & $\begin{array}{l}-0.0001 * \\
{[0.0000]}\end{array}$ & $\begin{array}{l}-0.0001 * \\
{[0.0000]}\end{array}$ \\
\hline Time dummies & No & Yes & Yes & Yes \\
\hline 2 digit SIC dummies & No & No & No & Yes \\
\hline Constant & $\begin{array}{c}5.3149 * * * \\
{[0.1213]}\end{array}$ & $\begin{array}{c}5.2408 * * * \\
{[0.1234]}\end{array}$ & $\begin{array}{c}5.0764 * * * \\
{[0.1406]}\end{array}$ & $\begin{array}{c}5.0841 * * * \\
{[0.1498]}\end{array}$ \\
\hline $\begin{array}{l}\text { Observations } \\
R^{2}\end{array}$ & $\begin{array}{l}6716 \\
0.204\end{array}$ & $\begin{array}{l}6716 \\
0.215\end{array}$ & $\begin{array}{l}6106 \\
0.231\end{array}$ & $\begin{array}{l}6106 \\
0.281\end{array}$ \\
\hline
\end{tabular}

* The dependent variable is total current compensation comprised of salary and bonus (tcc item in Execucomp). The main regressor of interest is $N O$ handicap, a dummy variable equal to 1 if the CEO is not present in any of the Golf Digest rankings.

Standard errors [in brackets] consistent in the presence of arbitrary within firm autocorrelation and heteroskedasticity (see Wooldridge 2002, eq. 7.26).

$* p<.10, * * p<.05, * * * p<.01$ 
Gueorgui I. Kolev \& Robin M. Hogarth: Illusory correlation in the remuneration of chief executive officers: It pays to play golf, and well.

Table 6: Regression of log of total current compensation* on golf handicap

\begin{tabular}{|c|c|c|c|c|}
\hline & $\begin{array}{c}(1) \\
\log \text { (total current } \\
\text { comp.) }\end{array}$ & $\begin{array}{c}\text { (2) } \\
\log \text { (total current } \\
\text { comp.) }\end{array}$ & $\begin{array}{c}\text { (3) } \\
\text { Log(total current } \\
\text { comp.) }\end{array}$ & $\begin{array}{c}\text { (4) } \\
\log (\text { total current } \\
\text { comp.) }\end{array}$ \\
\hline Handicap & $\begin{array}{l}-0.0050 \\
{[0.0062]}\end{array}$ & $\begin{array}{l}-0.0050 \\
{[0.0062]}\end{array}$ & $\begin{array}{c}-0.0066 \\
{[0.0070]}\end{array}$ & $\begin{array}{l}-0.0110 \\
{[0.0070]}\end{array}$ \\
\hline Log(mktvalue) & $\begin{array}{c}0.2005 * * * \\
{[0.0383]}\end{array}$ & $\begin{array}{c}0.2005^{* * *} * \\
{[0.0383]}\end{array}$ & $\begin{array}{c}0.1489 * * \\
{[0.0733]}\end{array}$ & $\begin{array}{c}0.0972 \\
{[0.0721]}\end{array}$ \\
\hline $\log ($ book/mkt value $)$ & & & $\begin{array}{l}0.1568^{*} \\
{[0.0932]}\end{array}$ & $\begin{array}{c}0.2094 * * * \\
{[0.0652]}\end{array}$ \\
\hline Return 1 year & & & $\begin{array}{c}0.0029 * * \\
{[0.0013]}\end{array}$ & $\begin{array}{c}0.0033 * * * \\
{[0.0010]}\end{array}$ \\
\hline Return 3 years & & & $\begin{array}{c}0.0113 * * * \\
{[0.0034]}\end{array}$ & $\begin{array}{c}0.0112^{* * *} \\
{[0.0031]}\end{array}$ \\
\hline ROA & & & $\begin{array}{c}0.0080 \\
{[0.0051]}\end{array}$ & $\begin{array}{c}0.0163 * * * \\
{[0.0053]}\end{array}$ \\
\hline Sales growth $3 y r s$ & & & $\begin{array}{c}-0.0037 \\
{[0.0036]}\end{array}$ & $\begin{array}{c}-0.0036 \\
{[0.0034]}\end{array}$ \\
\hline Employees & & & $\begin{array}{l}0.0010^{*} \\
{[0.0006]}\end{array}$ & $\begin{array}{l}0.0013 * * \\
{[0.0007]}\end{array}$ \\
\hline Dividend yield & & & $\begin{array}{c}0.0116 \\
{[0.0168]}\end{array}$ & $\begin{array}{c}0.0178 \\
{[0.0116]}\end{array}$ \\
\hline Price/earnings & & & $\begin{array}{c}0.0000 \\
{[0.0002]}\end{array}$ & $\begin{array}{c}0.0001 \\
{[0.0002]}\end{array}$ \\
\hline S\&P 500 dummy & & & $\begin{array}{c}0.2522 \\
{[0.1773]}\end{array}$ & $\begin{array}{l}0.2672 * \\
{[0.1613]}\end{array}$ \\
\hline Time dummies & No & Yes & Yes & Yes \\
\hline 2 digit SIC dummies & No & No & No & Yes \\
\hline Constant & $\begin{array}{c}5.7475 * * * \\
{[0.3757]}\end{array}$ & $\begin{array}{c}5.7475 * * * \\
{[0.3757]}\end{array}$ & $\begin{array}{c}5.9012 * * * \\
{[0.5289]}\end{array}$ & $\begin{array}{c}6.4156^{* * * *} \\
{[0.5770]}\end{array}$ \\
\hline $\begin{array}{l}\text { Observations } \\
R^{2}\end{array}$ & $\begin{array}{c}675 \\
0.124\end{array}$ & $\begin{array}{c}675 \\
0.124\end{array}$ & $\begin{array}{c}643 \\
0.225\end{array}$ & $\begin{array}{c}643 \\
0.338\end{array}$ \\
\hline
\end{tabular}

* The dependent variable is total current compensation comprised of salary and bonus (tcc item in Execuсотр). The main regressor of interest is Handicap, the golf handicap for the given year as reported in the relevant Golf Digest ranking.

Standard errors [in brackets] consistent in the presence of arbitrary within CEO autocorrelation and heteroskedasticity (see Wooldridge 2002, eq. 7.26).

$* p<.10, * * p<.05, * * * p<.01$ 
Table 7: Instrumental variable regression of log of total compensation* on golf handicap

\begin{tabular}{|c|c|c|c|c|}
\hline & $\begin{array}{c}(1) \\
\log (\text { total comp. } \\
\text { expected) }\end{array}$ & $\begin{array}{c}(2) \\
\log (\text { total comp. } \\
\text { expected })\end{array}$ & $\begin{array}{c}(3) \\
\log (\text { total comp. } \\
\text { expected })\end{array}$ & $\begin{array}{c}(4) \\
\log (\text { total comp. } \\
\text { expected })\end{array}$ \\
\hline Handicap & $\begin{array}{c}-0.0228^{* *} \\
{[0.0090]}\end{array}$ & $\begin{array}{c}-0.0231^{* *} \\
{[0.0090]}\end{array}$ & $\begin{array}{c}-0.0226^{* *} \\
{[0.0098]}\end{array}$ & $\begin{array}{c}-0.0320 * * * \\
{[0.0104]}\end{array}$ \\
\hline Log(mktvalue) & $\begin{array}{c}0.3045^{* * *} \\
{[0.0454]}\end{array}$ & $\begin{array}{c}0.3006^{* * *} \\
{[0.0452]}\end{array}$ & $\begin{array}{c}0.2780 * * * \\
{[0.0805]}\end{array}$ & $\begin{array}{c}0.2413 * * * \\
{[0.0881]}\end{array}$ \\
\hline $\log ($ book/mkt value $)$ & & & $\begin{array}{c}0.0833 \\
{[0.1161]}\end{array}$ & $\begin{array}{c}0.1392 \\
{[0.1064]}\end{array}$ \\
\hline Return 1 year & & & $\begin{array}{c}0.0013 \\
{[0.0018]}\end{array}$ & $\begin{array}{c}0.0022 \\
{[0.0017]}\end{array}$ \\
\hline Return 3 years & & & $\begin{array}{l}0.0087 * * \\
{[0.0040]}\end{array}$ & $\begin{array}{c}0.0085^{* *} \\
{[0.0039]}\end{array}$ \\
\hline ROA & & & $\begin{array}{c}-0.0025 \\
{[0.0117]}\end{array}$ & $\begin{array}{c}0.0039 \\
{[0.0134]}\end{array}$ \\
\hline Sales growth $3 y r s$ & & & $\begin{array}{c}-0.0067 \\
{[0.0043]}\end{array}$ & $\begin{array}{c}-0.0070 \\
{[0.0044]}\end{array}$ \\
\hline Employees & & & $\begin{array}{c}0.0004 \\
{[0.0005]}\end{array}$ & $\begin{array}{c}0.0009 \\
{[0.0006]}\end{array}$ \\
\hline Dividend yield & & & $\begin{array}{c}0.0054 \\
{[0.0250]}\end{array}$ & $\begin{array}{c}0.0273 \\
{[0.0181]}\end{array}$ \\
\hline Price/earnings & & & $\begin{array}{c}0.0003 \\
{[0.0002]}\end{array}$ & $\begin{array}{c}0.0003 \\
{[0.0002]}\end{array}$ \\
\hline S\&P 500 dummy & & & $\begin{array}{c}0.2497 \\
{[0.1932]}\end{array}$ & $\begin{array}{c}0.2386 \\
{[0.1876]}\end{array}$ \\
\hline Time dummies & No & Yes & Yes & Yes \\
\hline 2 digit SIC dummies & No & No & No & Yes \\
\hline Constant & $\begin{array}{c}6.2889 * * * \\
{[0.4705]}\end{array}$ & $\begin{array}{c}6.1395 * * * \\
{[0.4687]}\end{array}$ & $\begin{array}{c}6.0696 * * * \\
{[0.6232]}\end{array}$ & $\begin{array}{c}4.9277 * * * \\
{[0.7063]}\end{array}$ \\
\hline $\begin{array}{l}\text { Observations } \\
R^{2}\end{array}$ & $\begin{array}{c}676 \\
0.144 \\
\end{array}$ & $\begin{array}{c}676 \\
0.154 \\
\end{array}$ & $\begin{array}{c}644 \\
0.194 \\
\end{array}$ & $\begin{array}{c}644 \\
0.300 \\
\end{array}$ \\
\hline
\end{tabular}

-The dependent variable is the log of total compensation, comprised of Salary, Bonus, Other Annual, Total Value of Restricted Stock Granted, Total Value of Stock Options Granted (using BlackScholes), Long-Term Incentive Payouts, and All Other Total (tdc1 item in Execucomp). The main regressor of interest is Handicap, the golf handicap for the given year as reported in the relevant Golf Digest ranking. We compute the mean golf handicap for each CEO across the years in which he appears in the sample. The Handicap variable is instrumented with two dummy variables which take the value of 1 if the CEO falls in the top or middle terciles respectively of the distribution of the mean golf handicaps.

Standard errors [in brackets] consistent in the presence of arbitrary within CEO autocorrelation and heteroskedasticity (see Wooldridge 2002, eq. 8.33).

$* p<.10, * * p<.05, * * * p<.01$ 
Table 8: Instrumental variable regression of $\log$ of total current compensation* on playing golf

\begin{tabular}{|c|c|c|c|c|}
\hline & $\begin{array}{c}(1) \\
\log (\text { total current } \\
\text { comp.) }\end{array}$ & $\begin{array}{c}\text { (2) } \\
\log (\text { total current } \\
\text { comp. })\end{array}$ & $\begin{array}{c}\text { (3) } \\
\log (\text { total current } \\
\text { comp. })\end{array}$ & $\begin{array}{c}(4) \\
\log (\text { total current } \\
\text { comp.) }\end{array}$ \\
\hline Handicap & $\begin{array}{c}-0.0113 \\
{[0.0076]}\end{array}$ & $\begin{array}{c}-0.0111 \\
{[0.0075]}\end{array}$ & $\begin{array}{c}-0.0140 \\
{[0.0086]}\end{array}$ & $\begin{array}{c}-0.0199 * * \\
{[0.0091]}\end{array}$ \\
\hline Log(mktvalue) & $\begin{array}{c}0.2140 * * * \\
{[0.0388]}\end{array}$ & $\begin{array}{c}0.2006^{* * *} \\
{[0.0381]}\end{array}$ & $\begin{array}{c}0.1485^{* *} \\
{[0.0724]}\end{array}$ & $\begin{array}{c}0.0982 \\
{[0.0735]}\end{array}$ \\
\hline $\log ($ book/mkt value) & & & $\begin{array}{c}0.1513 \\
{[0.0930]}\end{array}$ & $\begin{array}{c}0.1979 * * * \\
{[0.0681]}\end{array}$ \\
\hline Return 1 year & & & $\begin{array}{l}0.0028 * * \\
{[0.0013]}\end{array}$ & $\begin{array}{c}0.0032 * * * \\
{[0.0010]}\end{array}$ \\
\hline Return 3 years & & & $\begin{array}{c}0.0113 * * * \\
{[0.0034]}\end{array}$ & $\begin{array}{c}0.0111 * * * \\
{[0.0032]}\end{array}$ \\
\hline ROA & & & $\begin{array}{l}0.0087 * \\
{[0.0052]}\end{array}$ & $\begin{array}{c}0.0172 * * * \\
{[0.0056]}\end{array}$ \\
\hline Sales growth $3 y r s$ & & & $\begin{array}{c}-0.0038 \\
{[0.0036]}\end{array}$ & $\begin{array}{c}-0.0039 \\
{[0.0036]}\end{array}$ \\
\hline Employees & & & $\begin{array}{l}0.0010 * \\
{[0.0006]}\end{array}$ & $\begin{array}{l}0.0013^{*} \\
{[0.0007]}\end{array}$ \\
\hline Dividend yield & & & $\begin{array}{c}0.0128 \\
{[0.0171]}\end{array}$ & $\begin{array}{c}0.0186 \\
{[0.0123]}\end{array}$ \\
\hline Price/earnings & & & $\begin{array}{c}0.0000 \\
{[0.0002]}\end{array}$ & $\begin{array}{c}0.0001 \\
{[0.0002]}\end{array}$ \\
\hline S\&P 500 dummy & & & $\begin{array}{c}0.2520 \\
{[0.1755]}\end{array}$ & $\begin{array}{c}0.2626 \\
{[0.1655]}\end{array}$ \\
\hline Time dummies & No & Yes & Yes & Yes \\
\hline 2 digit SIC dummies & No & No & No & Yes \\
\hline Constant & $\begin{array}{c}5.8205 * * * \\
{[0.4043]}\end{array}$ & $\begin{array}{c}5.8406^{* * * *} \\
{[0.3908]}\end{array}$ & $\begin{array}{c}6.0141 * * * \\
{[0.5461]}\end{array}$ & $\begin{array}{c}5.7454 * * * \\
{[0.5825]}\end{array}$ \\
\hline $\begin{array}{l}\text { Observations } \\
R^{2}\end{array}$ & $\begin{array}{c}675 \\
0.101\end{array}$ & $\begin{array}{c}675 \\
0.123\end{array}$ & $\begin{array}{c}643 \\
0.223\end{array}$ & $\begin{array}{c}643 \\
0.335 \\
\end{array}$ \\
\hline
\end{tabular}

*The dependent variable is total current compensation comprised of salary and bonus (tcc item in Execucomp). The main regressor of interest is Handicap, the golf handicap for the given year as reported in the relevant Golf Digest ranking. We compute the mean golf handicap for each CEO across the years in which he appears in the sample. The Handicap variable is instrumented with two dummy variables which take the value of 1 if the CEO falls in the top or middle terciles respectively of the distribution of the mean golf handicaps.

Standard errors [in brackets] consistent in the presence of arbitrary within CEO autocorrelation and heteroskedasticity (see Wooldridge 2002, eq. 8.33).

$* p<.10, * * p<.05, * * * p<.01$ 


\section{Appendix A}

Figure 1: Histograms of golf handicap by year (superimposed theoretical normal density, calibrated to have the same mean and standard deviation as the golf handicap distributions)
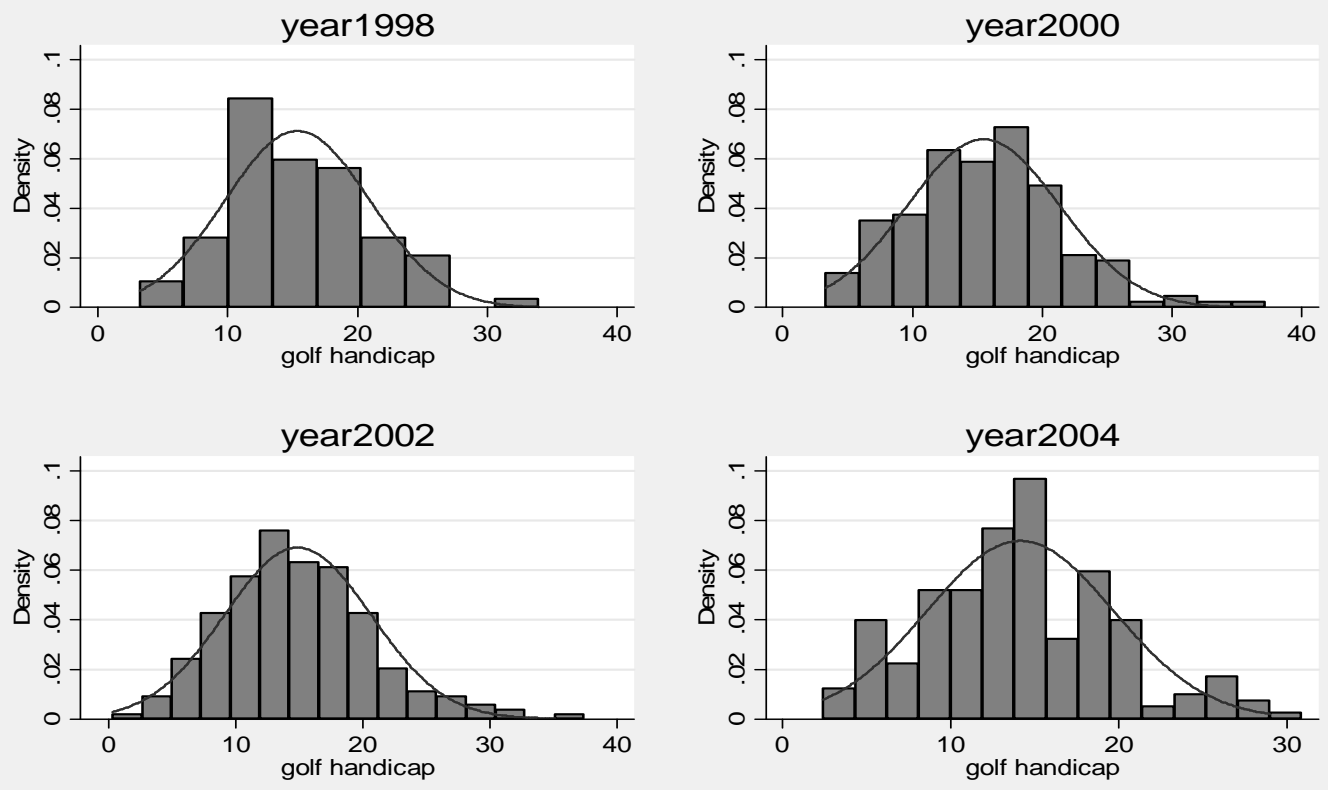

Figure 2: Scatter plot of current fiscal year shareholders' returns vs. current golf handicap
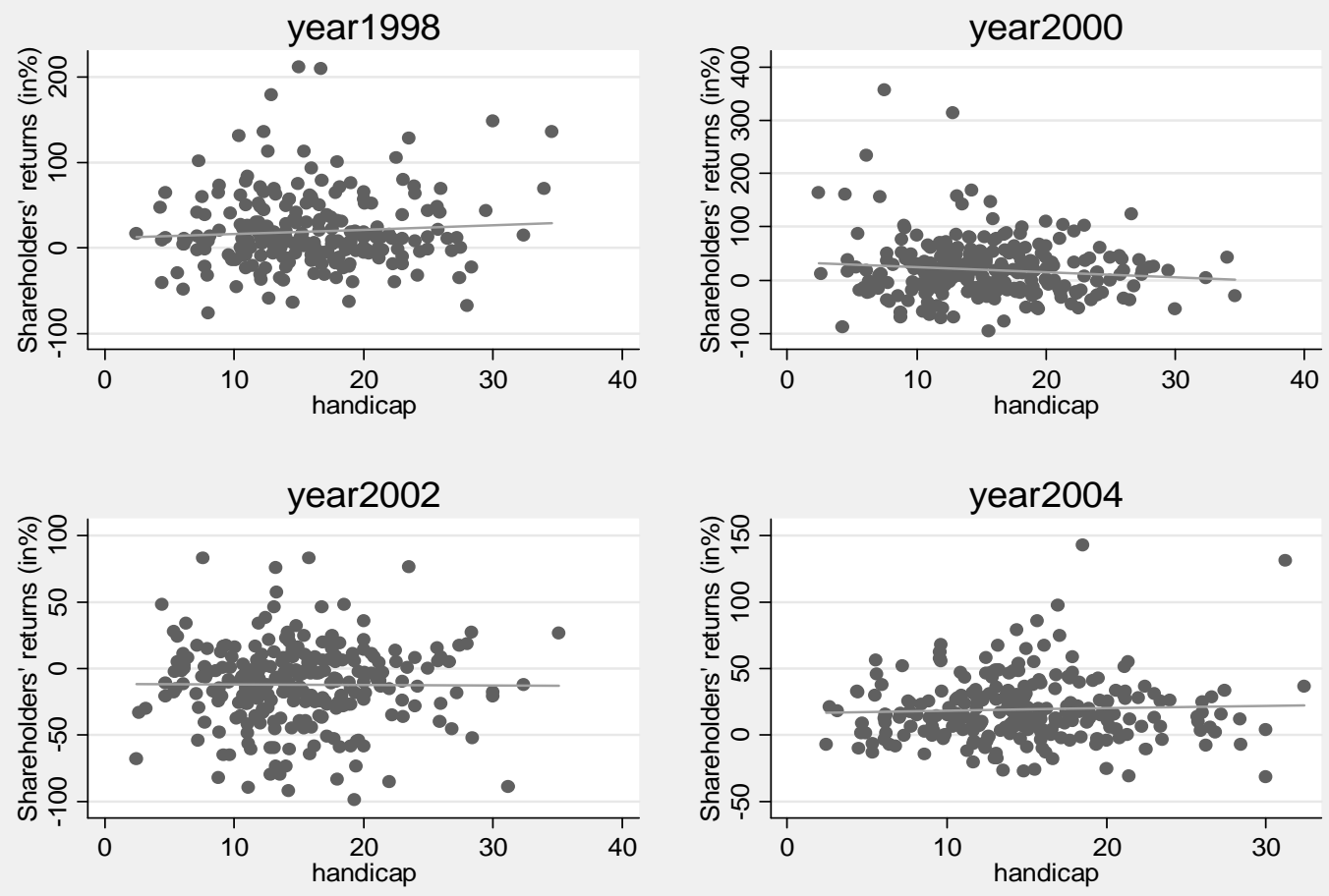
Figure 3: Scatter plot of next fiscal year shareholders' returns vs. current golf handicap
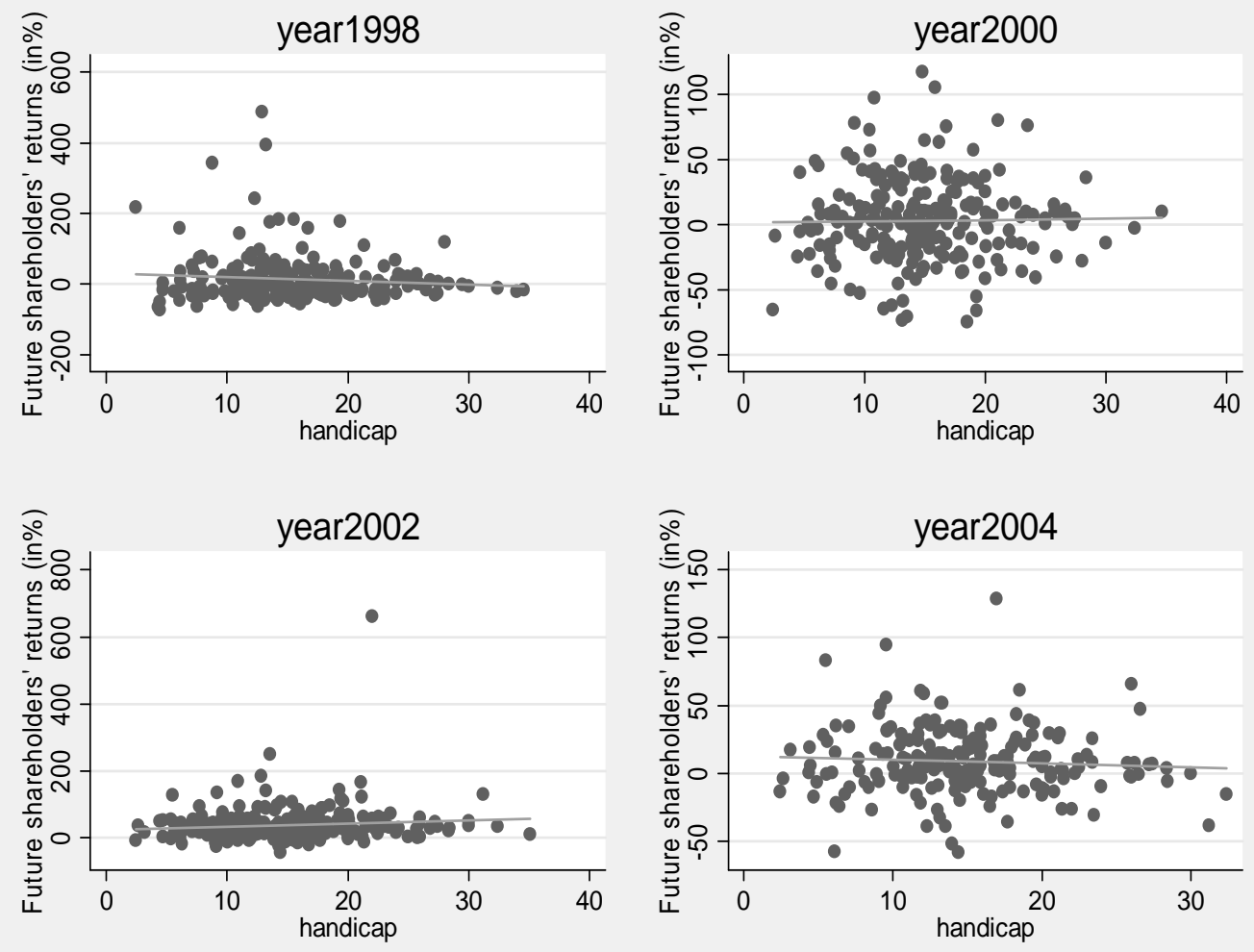

\section{Appendix B}

In this appendix we employ nonparametric nearest neighbour matching estimators (Imbens, 2004; Abadie, Drukker, Herr \& Imbens, 2004), which are potentially more appropriate for a binary "treatment" variable like No handicap. We present estimates of the Average Treatment Effect of not playing golf. The idea is that semi-parametric regression methods that we employ in Table 3 and Table 5 control for other covariates, but impose linearity on the relation between CEO compensation and the No handicap dummy variable and the other controls. The nonparametric nearest neighbour matching estimator finds for each firm in the sample with given value of the No handicap dummy, a firm which has the opposite value of No handicap, but is otherwise closest in the covariates space to the firm being matched. Then the Average Treatment Effect of not playing golf is estimated by the average 
Gueorgui I. Kolev \& Robin M. Hogarth: Illusory correlation in the remuneration of chief executive officers: It pays to play golf, and well.

difference between firms taking alternative treatment in the sample, where the average is taken over the set of matched pairs.

Overall, the effects estimated for CEO compensation from the nearest neighbour matching procedure are much larger than the effects estimated from the linear regression specifications, and they are significant at better than $0.1 \%$ level.

Table B.1: Nearest neighbour matching estimators of the Average Treatment Effect of the No handicap "treatment variable" on the dependent variable in the column's header (exact definitions of the dependent variables can be found in the notes to Tables 1,3 and 5). Exact matching on Year, nearest neighbour matching on Log firm market value and Log book to market ratio

\begin{tabular}{lcccc}
\hline & $(1)$ & $(2)$ & $(3)$ & $(4)$ \\
& Return 1 year & Future 1yr return & $\begin{array}{c}\text { Log(total comp. } \\
\text { expected) }\end{array}$ & $\begin{array}{c}\text { Log(total current } \\
\text { comp.) }\end{array}$ \\
\hline NO handicap (ATE) & 112.2687 & 4.0429 & -0.2730 & -0.2961 \\
(Standard Error) & $(218.2458)$ & $(4.9336)$ & $(0.0812)$ & $(0.0701)$ \\
[p-value] & {$[0.607]$} & {$[0.413]$} & {$[0.001]$} & {$[0.000]$} \\
\hline
\end{tabular}

Table B.2: Nearest neighbour matching estimators of the Average Treatment Effect of the No handicap "treatment variable" on the dependent variable in the column's header (exact definitions of the dependent variables can be found in the notes to tables 3 and 5). Exact matching on Year and Two digit SIC industry classification, nearest neighbour matching on Log firm market value and Log book to market ratio, One year total shareholders returns and all the other covariates included in the Column 4 of Tables 3 and 5 regression specifications. Hence the estimate in Column (1) below is comparable to the estimate in Table 3, Column 4, and the estimate in Column (2) below is comparable to the estimate in Table 5, Column 4.

\begin{tabular}{lcc}
\hline & $(1)$ & $(2)$ \\
& $\begin{array}{c}\text { Log(total comp. } \\
\text { expected) }\end{array}$ & $\begin{array}{c}\text { Log(total current } \\
\text { comp.) }\end{array}$ \\
\hline NO handicap (ATE) & -0.5035 & -0.4210 \\
(Standard Error) & $(0.0729)$ & $(0.063236)$ \\
[p-value] & {$[0.000]$} & {$[0.000]$} \\
\hline
\end{tabular}




\section{Appendix C}

In this appendix we carry out calendar time performance attribution regressions (Jensen, 1968; Carhart, 1997) to study the long term impact of golf playing on shareholders' returns. For each month from January 1998 to December 2006, for a total of 108 months, we compute the equally(columns 1, 2 and 3) and value weighted (columns 4, 5 and 6) returns of a portfolio which is

a) long in firms with CEOs who do not appear in any Golf Digest ranking and short in firms with CEOs who appear in any ranking (Table C.1)

b) long in firms with CEOs who are in the second tercile of the mean golf handicap distribution (good but not exceptional golf players) and short in firms with CEOs who are in the first tercile of the mean golf handicap distribution (exceptionally good golf players) (Table C.2)

c) long in firms with CEOs who are in the third tercile of the mean golf handicap distribution (relatively bad golf players) and short in firms with CEOs who are in the first tercile of the mean golf handicap distribution (exceptionally good golf players) (Table C.3).

The mean golf handicap distribution and its terciles are computed as for the instrumental variables used in Tables 7 and 8 . The whole sample of firms on which the computations are based are the successful matches resulting from merging Execucomp to CRSP data. ${ }^{13}$

For each portfolio in a), b) and c) this results in time series of monthly returns, which are regressed on the monthly time series of returns of a set of "risk" factors. In the one factor model the only risk factor is the return on the value weighted market portfolio minus the risk free rate. In the three factor model (Fama \& French, 1993) the risk factors are the returns on the value weighted market portfolio minus the risk free rate, the high book to market minus low book to market firms portfolio and the small firms minus big firms portfolio. In the four factor model the momentum factor (Jegadeesh \& Titman, 1993; Carhart, 1997) is added to the previously mentioned three factors. Time series of the factor returns are downloaded from Kenneth R. French's website (http://mba.tuck.dartmouth.edu/pages/faculty/ken.french/data_library.html).

\footnotetext{
${ }^{13}$ The matching variable from Execucomp used to identify firms is cusip, and the matching variable from CRSP used to identify firms is ncusip.
} 
Gueorgui I. Kolev \& Robin M. Hogarth: Illusory correlation in the remuneration of chief executive officers: It pays to play golf, and well.

The returns on the portfolios are regressed on the risk factors and the constant term of this regression, known as Jensen's alpha, represents the average risk adjusted abnormal return the portfolio generates after controlling for the known risk factors. For example if the portfolio strategy long in bad golf players (top tercile) and short in good golf players (bottom tercile) generates positive statistically significant and economically large Jensen's alpha, we can conclude that bad golf players outperform good golf players in the long run and generate abnormal returns even after appropriately controlling for risk.

The following three tables show that Jensen's alphas are never significant at conventional levels and the signs of the risk adjusted abnormal returns generated do not follow any consistent pattern. Hence we conclude that golf playing in not informative for long term performance of the CEOs.

Table C.1 The dependent variable is equally weighted (EW) and value weighted (VW) monthly return difference between firms with CEOs who do not appear in any Golf Digest ranking (long position) and firms with CEOs who appear in any Golf Digest ranking (short position)

\begin{tabular}{|c|c|c|c|c|c|c|}
\hline & (1) & (2) & (3) & (4) & (5) & $\begin{array}{c}(6) \\
\text { VW ret diff }\end{array}$ \\
\hline Mkt-rf & $\begin{array}{c}0.2583 * * * \\
{[0.0447]}\end{array}$ & $\begin{array}{c}0.1087 * * * \\
{[0.0215]}\end{array}$ & $\begin{array}{c}0.0893^{* * * *} \\
{[0.0223]}\end{array}$ & $\begin{array}{c}0.2293^{* * *} \\
{[0.0439]}\end{array}$ & $\begin{array}{c}0.1335^{* * * *} \\
{[0.0416]}\end{array}$ & $\begin{array}{c}0.1608 * * * \\
{[0.0437]}\end{array}$ \\
\hline High-Low & & $\begin{array}{c}-0.0898 * * * \\
{[0.0277]}\end{array}$ & $\begin{array}{c}-0.0977 * * * \\
{[0.0272]}\end{array}$ & & $\begin{array}{c}-0.0512 \\
{[0.0536]}\end{array}$ & $\begin{array}{c}-0.0402 \\
{[0.0534]}\end{array}$ \\
\hline Small-Big & & $\begin{array}{c}0.4227 * * * \\
{[0.0222]}\end{array}$ & $\begin{array}{c}0.4363 * * * \\
{[0.0222]}\end{array}$ & & $\begin{array}{c}0.2825 * * * \\
{[0.0429]}\end{array}$ & $\begin{array}{c}0.2635^{* * * *} \\
{[0.0436]}\end{array}$ \\
\hline Momentum & & & $\begin{array}{c}-0.0381 * * \\
{[0.0149]}\end{array}$ & & & $\begin{array}{l}0.0537^{*} \\
{[0.0291]}\end{array}$ \\
\hline $\begin{array}{l}\text { Constant } \\
\text { (Jensen's alpha) }\end{array}$ & $\begin{array}{c}0.1549 \\
{[0.2066]}\end{array}$ & $\begin{array}{c}0.0967 \\
{[0.0868]}\end{array}$ & $\begin{array}{c}0.1320 \\
{[0.0857]}\end{array}$ & $\begin{array}{l}-0.1313 \\
{[0.2030]}\end{array}$ & $\begin{array}{l}-0.1765 \\
{[0.1678]}\end{array}$ & $\begin{array}{l}-0.2262 \\
{[0.1681]}\end{array}$ \\
\hline $\begin{array}{l}\text { Observations } \\
R^{2}\end{array}$ & $\begin{array}{c}108 \\
0.240\end{array}$ & $\begin{array}{c}108 \\
0.878\end{array}$ & $\begin{array}{c}108 \\
0.885\end{array}$ & $\begin{array}{c}108 \\
0.205\end{array}$ & $\begin{array}{c}108 \\
0.506\end{array}$ & $\begin{array}{c}108 \\
0.521\end{array}$ \\
\hline
\end{tabular}

Standard errors in brackets

$* p<.10, * * p<.05, * * * p<.01$ 
Table C. 2 The dependent variable is equally weighted (EW) and value weighted (VW) monthly return difference between firms with CEOs in the second tercile of the mean golf handicap distribution (long position consists of average golf players) and firms with CEOs in the first tercile of the mean golf handicap distribution (short position consists of excellent golf players)

\begin{tabular}{|c|c|c|c|c|c|c|}
\hline & $\begin{array}{c}(1) \\
\text { EW ret diff }\end{array}$ & $\begin{array}{c}(2) \\
\text { EW ret diff }\end{array}$ & $\begin{array}{c}\text { (3) } \\
\text { EW ret diff }\end{array}$ & $\begin{array}{c}\text { (4) } \\
\text { VW ret diff }\end{array}$ & $\begin{array}{c}(5) \\
\text { VW ret diff }\end{array}$ & $\begin{array}{c}\text { (6) } \\
\text { VW ret diff }\end{array}$ \\
\hline Mkt-rf & $\begin{array}{c}0.0862 * * * \\
{[0.0302]}\end{array}$ & $\begin{array}{c}0.0520 \\
{[0.0350]}\end{array}$ & $\begin{array}{c}0.0247 \\
{[0.0395]}\end{array}$ & $\begin{array}{c}-0.1279 * * \\
{[0.0600]}\end{array}$ & $\begin{array}{c}-0.1337 * * \\
{[0.0533]}\end{array}$ & $\begin{array}{c}-0.1805 * * * \\
{[0.0577]}\end{array}$ \\
\hline High-Low & & $\begin{array}{l}-0.0466 \\
{[0.0444]}\end{array}$ & $\begin{array}{c}-0.0576 \\
{[0.0443]}\end{array}$ & & $\begin{array}{c}-0.0214 \\
{[0.1037]}\end{array}$ & $\begin{array}{c}-0.0403 \\
{[0.0950]}\end{array}$ \\
\hline Small-Big & & $\begin{array}{c}0.0483 \\
{[0.0413]}\end{array}$ & $\begin{array}{c}0.0674 \\
{[0.0449]}\end{array}$ & & $\begin{array}{l}-0.0168 \\
{[0.1015]}\end{array}$ & $\begin{array}{c}0.0158 \\
{[0.0893]}\end{array}$ \\
\hline Momentum & & & $\begin{array}{l}-0.0536^{*} \\
{[0.0285]}\end{array}$ & & & $\begin{array}{c}-0.0918 \\
{[0.0690]}\end{array}$ \\
\hline $\begin{array}{l}\text { Constant } \\
\text { (Jensen's alpha) }\end{array}$ & $\begin{array}{c}0.0500 \\
{[0.1416]}\end{array}$ & $\begin{array}{c}0.0692 \\
{[0.1515]}\end{array}$ & $\begin{array}{c}0.1190 \\
{[0.1510]}\end{array}$ & $\begin{array}{c}0.0447 \\
{[0.2635]}\end{array}$ & $\begin{array}{c}0.0649 \\
{[0.2950]}\end{array}$ & $\begin{array}{c}0.1499 \\
{[0.2690]}\end{array}$ \\
\hline $\begin{array}{l}\text { Observations } \\
R^{2}\end{array}$ & $\begin{array}{c}108 \\
0.068\end{array}$ & $\begin{array}{c}108 \\
0.109\end{array}$ & $\begin{array}{c}108 \\
0.147\end{array}$ & $\begin{array}{c}108 \\
0.043\end{array}$ & $\begin{array}{c}108 \\
0.044\end{array}$ & $\begin{array}{c}108 \\
0.075\end{array}$ \\
\hline
\end{tabular}

Standard errors in brackets

$* p<.10, * * p<.05, * * * p<.01$

Table C.3 The dependent variable is equally weighted (EW) and value weighted (VW) monthly return difference between firms with CEOs in the third tercile of the mean golf handicap distribution (long position consists of relatively bad golf players) and firms with CEOs in the first tercile of the mean golf handicap distribution (short position consists of excellent golf players)

\begin{tabular}{|c|c|c|c|c|c|c|}
\hline & $\begin{array}{c}(1) \\
\text { EW ret diff }\end{array}$ & $\begin{array}{c}(2) \\
\text { EW ret diff }\end{array}$ & $\begin{array}{c}\text { (3) } \\
\text { EW ret diff }\end{array}$ & $\begin{array}{c}(4) \\
\text { VW ret diff }\end{array}$ & $\begin{array}{c}(5) \\
\text { VW ret diff }\end{array}$ & $\begin{array}{c}\text { (6) } \\
\text { VW ret diff }\end{array}$ \\
\hline Mkt-rf & $\begin{array}{c}-0.0512 \\
{[0.0357]}\end{array}$ & $\begin{array}{c}0.0113 \\
{[0.0349]}\end{array}$ & $\begin{array}{c}-0.0263 \\
{[0.0364]}\end{array}$ & $\begin{array}{c}-0.2140 * * \\
{[0.0871]}\end{array}$ & $\begin{array}{c}-0.0712 \\
{[0.0860]}\end{array}$ & $\begin{array}{l}-0.0869 \\
{[0.0912]}\end{array}$ \\
\hline High-Low & & $\begin{array}{c}0.1422 * * * \\
{[0.0537]}\end{array}$ & $\begin{array}{l}0.1270 * * \\
{[0.0509]}\end{array}$ & & $\begin{array}{c}0.3111 * * * \\
{[0.1139]}\end{array}$ & $\begin{array}{c}0.3047 * * * \\
{[0.1117]}\end{array}$ \\
\hline Small-Big & & $\begin{array}{c}0.0179 \\
{[0.0370]}\end{array}$ & $\begin{array}{c}0.0441 \\
{[0.0391]}\end{array}$ & & $\begin{array}{c}0.0150 \\
{[0.0917]}\end{array}$ & $\begin{array}{c}0.0259 \\
{[0.0971]}\end{array}$ \\
\hline Momentum & & & $\begin{array}{c}-0.0737 * * \\
{[0.0344]}\end{array}$ & & & $\begin{array}{c}-0.0308 \\
{[0.0665]}\end{array}$ \\
\hline $\begin{array}{l}\text { Constant } \\
\text { (Jensen's alpha) }\end{array}$ & $\begin{array}{l}-0.0902 \\
{[0.1382]}\end{array}$ & $\begin{array}{l}-0.1968 \\
{[0.1386]}\end{array}$ & $\begin{array}{l}-0.1284 \\
{[0.1385]}\end{array}$ & $\begin{array}{c}0.1345 \\
{[0.3041]}\end{array}$ & $\begin{array}{l}-0.0918 \\
{[0.2943]}\end{array}$ & $\begin{array}{l}-0.0632 \\
{[0.3037]}\end{array}$ \\
\hline $\begin{array}{l}\text { Observations } \\
R^{2}\end{array}$ & $\begin{array}{c}108 \\
0.027 \\
\end{array}$ & $\begin{array}{c}108 \\
0.127 \\
\end{array}$ & $\begin{array}{c}108 \\
0.207 \\
\end{array}$ & $\begin{array}{c}108 \\
0.093 \\
\end{array}$ & $\begin{array}{c}108 \\
0.192 \\
\end{array}$ & $\begin{array}{c}108 \\
0.195 \\
\end{array}$ \\
\hline
\end{tabular}

Standard errors in brackets

$* p<.10, * * p<.05, * * * p<.01$ 